\section{Lucija Vuković}

Muzeji i galerije Konavala, Cavtat

Izvorni znanstveni rad / Original scientific paper

UDK / UDC: 728.82(497.5-3 Konavle)

29. 7. 2013.

\title{
Ladanjsko-gospodarska arhitektura u Konavlima
}

Ključne riječi: ladanjsko-gospodarska arhitektura, Dubrovačka Republika, Konavle Key words: residential-farming architecture, Dubrovnik Republic, Konavle

Nakon što se u 15. stoljeću, kao zadnji dio teritorija kojim se zaokružuju granice, Konavle priključuju Dubrovačkoj Republici, ladanjska izgradnja širi se i na ovo područje. Konavle postaju žitnica Republike, a na posjedima dubrovačke vlastele u gotovo svim dijelovima Konavala grade se kompleksi koji u svojoj formi objedinjuju prevladavajuću gospodarsku i nešto skromniju ladanjsku funkciju. Na primjerima pet odabranih objekata opisuju se arhitektonske značajke ladanjsko-gospodarske arhitekture u Konavlima te se skreće pozornost na sadašnju poziciju ovoga graditeljskog naslijeđa.

Ladanjska arhitektura dubrovačkog područja tema je o kojoj su napisani mnogi znanstveni radovi, međutim područje Konavala u tom kontekstu tek je dotaknuto. ${ }^{1}$ Ladanjskogospodarski kompleksi u Konavlima nikada nisu sustavno istraživani, nisu čak ni evidentirani u potpunosti, a dokument pravne zaštite postoji trenutačno za dva objekta. Najveći broj ih je danas u ruševnom stanju, zapušteni su ili kasnijim intervencijama bitno izmijenjeni. Knežev dvor u Pridvorju, s padom Republike i prilikom prodora Crnogoraca u Konavle 1806. godine, jest spaljen, a s njime i velik dio arhivske građe koja je tada bila pohranjena u njemu. ${ }^{2}$

Prije ulaska u sastav Dubrovačke Republike Konavle su bile nestabilno područje potresano brojnim nemirima. ${ }^{3}$ Dubrovnik je za vrijeme širenja svojih posjeda imao gospodarske i strateške razloge zbog kojih je još od 1358. godine, upirući sve diplomatske snage, nastojao priključiti Konavle svom teritoriju. Od najveće važnosti bilo je stjecanje velikog dijela plodne zemlje i stvaranje stabilne granice prema nemirnom zaleđu. Unatoč diplomatskoj spretnosti dubrovačke vlastele, ne polazi im za rukom lako steći to područje, kao ni održati ga bez sukoba i nemira. ${ }^{4}$

Na početku 15. stoljeća jedan dio središnjeg i istočnog dijela Konavala u rukama je vojvode Sandalja Hranića, dok zapadni dio pripada bosanskim feudalcima braći Pavlovićima. ${ }^{5}$ Nakon dugih pregovora Dubrovčani 1419. godine uspijevaju kupiti Sandaljevu polovicu za 12000 dukata i 500 perpera godišnje. ${ }^{6}$ Uz novac, Sandalj i sinovi su dobili dubrovačku plemićku titulu, imanje u Župi i kuću u Dubrovniku. ${ }^{7}$

Godine 1426., nakon višegodišnjih pregovora, Radoslav Pavlović pristao je na prodaju zapadnog dijela Konavala sa Cavtatom i Obodom za svotu od 13000 dukata, 600 perpera godišnje, dio zemljišta u Konavlima i kuću u Dubrovniku. ${ }^{8}$

Novostečena zemlja podijeljena je u desetine, ${ }^{9}$ a svakoj konavoskoj desetini određen je glavar. Osim dubrovačke vlastele kojoj je dodijeljen najveći dio zemlje, određeni dio zemlje pripao je građanima, Crkvi, Općini (za općinske zgrade, putove, lokve, izvore, ciglane), bosanskom kralju, hrvatskom banu te vlasteličićima iz Sandaljeva dijela. ${ }^{10}$

Od samih početaka Republika usmjerava Konavle na proizvodnju žita jer je Dubrovnik dotada uvozio žito iz Apulije, Sicilije, Albanije i zemalja Levanta. Skromni prinosi koje je davala primorska zemlja nisu mogli ni blizu osigurati potrebe za žitom povećanog broja stanovništva u gradu i okolici. Kao i u Primorju, u Konavlima se ograničava sadnja vinograda. Novostečena konavoska zemlja zasijana je pšenicom, ječmom, zobi i prosom. Zemljište na kojem se 
uzgajalo žito davalo se u zakup, a prevladava način ugovaranja na novčanu rentu. Djelomično ostaje davanje u naturi, pa je seljak od cijelog prinosa bio dužan dati gospodaru jednu četvrtinu žita. ${ }^{11}$

Nakon uspostave vlasti i podjele zemlje, Dubrovčani su započeli planiranu i brojnim odredbama reguliranu izgradnju na području Konavala, kao što je to bio slučaj i u ostalim novostečenim područjima. U 15. stoljeću, kada su Konavle potresane brojnim bunama i oružanim sukobima a Osmanlije još uvijek blizu, najvažnije je bilo zaštititi se od moguće opasnosti. Tvrđava Sokol se znatno proširuje. ${ }^{12}$ $\mathrm{U}$ njezinu sklopu gradi se kapelica ${ }^{13}$ i Sokol postaje sjedište kaštelana, glavnoga vojnog komandanta za ovo područje.

$\mathrm{Na}$ istočnom i zapadnom kraju Konavala, na dva poluotoka koja je lako braniti, Moluntu i Cavtatu, grade se utvrđeni zbjegovi u koje bi se stanovništvo sklonilo u slučaju opasnosti. Cavtat je određen za jedno od središta uprave pa se od 1555. do 1558. godine uz gradska vrata gradi Knežev dvor, udoban ljetnikovac s prednjim i stražnjim vrtom. Drugi Knežev dvor je izgrađen u Pridvorju, u središnjem dijelu Konavala. Gradnja dvorova praćena je izgradnjom franjevačkih samostana. ${ }^{14}$

U prvoj polovini 15 . stoljeća malobrojni dubrovački vlasteoski rodovi povećali su broj svojih posjeda za one koje su dobili u diobama zemlje u Konavlima. Ubrzo se pokazalo da upravljanje i kontrola nad posjedom traže i gradnju na njemu, osobito zbog velike udaljenosti od grada. Postupno se stabiliziraju prilike u ovim krajevima što pogoduje intenziviranju izgradnje na vlastelinskim posjedima pa se prijašnjim objektima pretežno gospodarskog karaktera (»stranjevima«) ${ }^{15}$ sada priključuju i nešto prostraniji i opremljeniji stambeni dijelovi.

Najveća koncentracija ladanjsko-gospodarskih objekata je u donjoj strani Konavala, osobito u njezinu zapadnom dijelu: Čilipima, Močićima, Komajima, Radovčićima. U »Gornjoj bandi« žarište najgušće izgradnje bilo je Pridvorje, i to neposredna okolica Kneževa dvora. Nekoliko objekata nalazimo u Dubravci, potom u Zastolju, Lovornom, Ljutoj, Mihanićima. Sudeći po francuskom izvješću o štetama provedenom 1806. godine, gotovo u svakom naselju možemo evidentirati vlastelinski objekt, stranj ili kuću. ${ }^{16}$ Najčešće su smješteni uz glavne prometnice pa vlasnik može konjem doći do samog zdanja, a seljacima je olakšano dovoženje ljetine i prinosa svom gospodaru.

Kompleksi su imali izraženu gospodarsku namjenu kojoj je unutar cjeline bilo sve podređeno. Unutar visokih ogradnih zidova sa širokim ulaznim portalom, raspoređeni su dominantni gospodarski i nešto skromniji stambeni sadržaji te vrt. Svi veći kompleksi imali su i kapelicu.

Glavna zgrada ističe se veličinom, načinom obrade zida i okvira otvora te opremljenošću unutrašnjosti. Ona gotovo uvijek ima dvojnu funkciju - stambeni kat i gospodarsko prizemlje, a nalazimo i primjere kada je potkrovlje također korišteno u gospodarske svrhe. Prizemlje je otvoreno širokim ulazom i rijetkim prozorima malih dimenzija.

Dok je u dubrovačkim ljetnikovcima bio ustaljen tlocrtni raspored sa središnjom saločom i bočnim sobama, u Konavlima ga sa sigurnošću evidentiramo tek $\mathrm{u}$ »Diklićevoj taraci« $\mathrm{u}$ Čilipima-Masješama. Ne postoji pravilo tlocrtnog rasporeda, iako uvijek prepoznajemo središnju prostoriju koja je najčešće opremljena kamenim namještajem i koja je višestruko povezana s unutrašnjim i vanjskim dijelovima sklopa.

Zidovi glavne zgrade rastvoreni su u pravilu pravokutnim otvorima. Na pročelju su otvori brojniji i pravilnije raspoređeni. Okviri tih otvora razlikuju se od ostalih tek time što su nešto finije klesani, na katu velike kuće "Diklićeve tarace« ukrašeni su profiliranim prozorskim klupicama i vijencima, dok skromni rubni štap krasi otvore kuće PucićRešetar u Čilipima.

Oko glavne zgrade grupirane su građevine gospodarske namjene, prizemnice građene grublje obrađenim kamenim blokovima. U njima su smješteni magazini, vinice, mlinice, kovačnice, konjušnice, štale... Mogu se naslanjati na glavnu zgradu i tvoriti pravilan niz kao što je to slučaj kod dva susjedna kompleksa u Čilipima, Pucić-Rešetar i Getaldić-Vezelić, ili u nešto nepravilnijoj varijanti u kompleksima Crijević-Lobro u Radovčićima i Božidarević-Bačan u Komajima-Grušićima. U nekim slučajevima one su zasebne slobodnostojeće zgrade. Najveći dio ladanjsko-gospodarskih sklopova u Konavlima građen je na osami, na otvorenom prostoru koji dopušta brojne pregradnje i promjene prostornih odnosa. Takav primjer je ladanjsko-gospodarski kompleks Ranjina-Capor u Vignjima na kojem su vidljive brojne faze gradnje.

Svaki ladanjsko-gospodarski kompleks ima barem jednu cisternu, često smještenu ispod kuće (kompleksi u Radovčićima i Grušićima, Bona-Bakić-Korda i Pucić-Rešetar u Čilipima) ili u prednjem ili stražnjem vrtu (kompleksi „Frančesko« u Čilipima i Natalić-Kocelj-Montgomery u Močićima). Krune bunara su jednostavno oblikovane, četverostrane ili okrugle, ili pak kružna baza završava četverokutnim vijencem. Iznimku čini kruna bunara čilipskog kompleksa Getaldić-Vezilić na kojoj je isklesan vlasteoski grb. U gornjoj strani Konavala koja je bogatija vodom kompleksi se smještaju uz izvore vode i potoke (Saraka-Pulić u Dubravci-Pičetama, Vodopić-Car u Zastolju).

Neizostavan dio konavoskoga ladanjsko-gospodarskog sklopa je otvorena ili krušna peć, elementi karakteristični za tradicijsku arhitekturu ovog područja. "Diklićeva taraca» i kompleks Ranjina-Capor imaju zasebne prostorije s ovakvim pećima, kuhinje izgrađene u sklopu kuće. U Pucićevu sklopu u Čilipima i Božidarevićevu u Grušićima ostatke peći nalazimo u prizemlju glavne zgrade, a unutar kompleksa »Frančesko» sačuvana je iza kuće velika slobodnostojeća krušna peć.

Unutar svih većih ladanjsko-gospodarskih kompleksa nalazi se kapelica koja je najčešće smještena u vrtu i povezana sa šetnicom. U pravilu je pravokutna i presvođena 
bačvastim svodom. Iako je njezina arhitektonska dekoracija relativno skromna, ograničena na jednostavno ukrašene okvire otvora, rozetu i preslicu, kapelica je najraskošnije opremljena građevina sklopa koja u najvećoj mjeri nosi stilske oznake razdoblja u kojem nastaje. Kapelicama se u ovom području, osim vlasnika, koristilo i okolno stanovništvo. U Močićima nalazimo lijep primjer Natalićeve kapelice Male Gospe čije je pročelje s glavnim ulazom okrenuto cesti i okolnom krajoliku, dok vlasnik koristi privatni ulaz na bočnoj fasadi okrenutoj prema vrtu.

Vrtovi ladanjsko-gospodarskih sklopova u Konavlima rijetko su sačuvani u izvornom obliku. Ipak, gotovo redovito nalazimo zidane spremnice za zemlju na koje su oslonjeni stupovi odrine. Stupovi su oktogonalnoga, okruglog ili četvrtastog presjeka, s jednostavnim kapitelima i često usađeni u četvrtasti kameni postament. Odrina se najčešće pružala pred pročeljem glavne zgrade oslonjena na kamene konzole ili su je podržavale rupe u zidu. Šetnice koje su presijecale vrtove negdje su bile popločane. Najljepši primjer vrta unutar ladanjskog sklopa svakako je onaj »Diklićeve tarace» u Masješama s pravilnom podjelom vrtnih površina i dugačkom šetnicom-vidikovcem koja se pruža rubom terase na kojoj je vrt smješten.

Od kamenog namještaja nalazimo zidne umivaonike (pila) i zidne ormare kao opremu središnjih dvorana ili kuhinja. Ormari najčešće imaju jednostavne ravne kamene okvire te kamene police ili tek žljebove za umetanje drvenih polica. Zidni umivaonici često imaju svoje mjesto uz grlo bunara. Nalazimo samo plitke bazene isklesane u kamenim pločama i umetnute u zidne niše bez okvira, zatim pila sa središnjom policom jednostavnih glatkih kamenih okvira, ukrašenih tek nizom denta ili profilacijom umjesto baza i kapitela. Raskošnije je ukrašen bazen pila "Diklićeve tarace" motivom izmjeničnih zubaca, te okvir kasnorenesansnoga zidnog umivaonika u Radovčićima, s plitkom kontinuiranom profilacijom, nizom denta nad poprečnom gredom i motivom školjke.

Ovdje navedene osnovne oznake ladanjsko-gospodarskih kompleksa u Konavlima detaljnije su opisane kod nekoliko izabranih primjera.

\section{Ladanjsko-gospodarski \\ kompleks Crijević-Lobro \\ u Radovčićima}

Ladanjsko-gospodarski kompleks u Radovčićima u 19. stoljeću pripadao je obitelji Crijević. ${ }^{17}$ Danas je u vlasništvu obitelji Lobro. Najslavniji vlasnik ovog objekta je dubrovački pjesnik Dominko Zlatarić (1558.-1613.), a o boravku njega i njegovih prijatelja latinista na konavoskom ladanju ostala

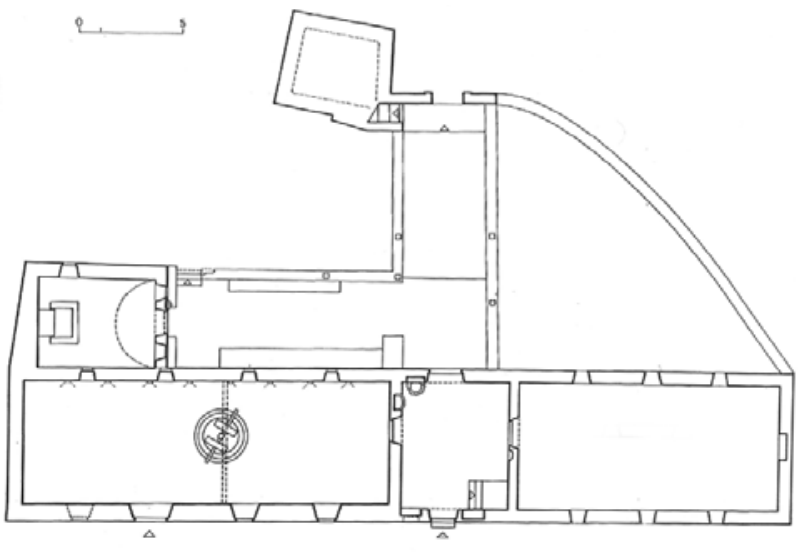

1. Ladanjsko-gospodarski kompleks Crijević-Lobro, Radovčići, tlocrt / The residential-farming complex Crijević-Lobro, Radovčići, ground plan

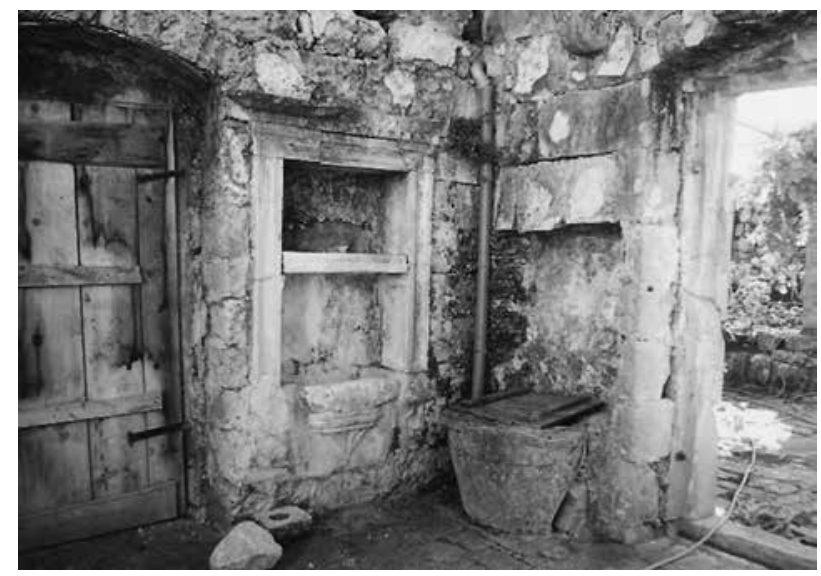

2. Ladanjsko-gospodarski kompleks Crijević-Lobro, Radovčići, zidni umivaonik u prizemlju / The residential-farming complex Crijević-Lobro, Radovčicii, wall wash-basin on the ground floor

su nam svjedočanstva u pjesmama Camilla Camillija i Didaka Pira. ${ }^{18}$ Kompleks se sastoji od nekada jednokatnoga stambenog dijela i dviju gospodarskih prizemnica građenih u nizu. Ostali dio kompleksa čine kapelica, šetnica i vrt koji su smješteni u stražnjem dijelu.

Stambeni dio nalazi se u središtu kompleksa i vratima komunicira sa svim ostalim dijelovima. Danas je vidljiv do visine stropa prizemlja. Prizemlje je popločano i opremljeno kamenim namještajem. Djelomično su sačuvane profilirane konzole na uobičajenom mjestu uz prozorske klupice te one u unutrašnjosti koje su nosile stropne grede.

Kruna bunara smještena je u ožbukanoj zidnoj niši uz ulaz iz šetnice. Uz nju je kasnorenesansno pilo čiji je okvir, jednako kao i središnja polica oslonjena na reljefne konzolice, ukrašen kontinuiranom plitkom profilacijom. Na vrhu je kameni vijenac s nizom denta. U donjem dijelu je ploča s plitkim reljefom školjke. ${ }^{19}$ Zidni ormar u dnu nekadašnjeg stubišta jednostavnog je kamenog okvira sa žljebovima za 
police, a od zidnog namještaja na katu sačuvana je samo ploča s reljefom školjke, nešto finije i mekše obrade od one u prizemlju. Ukrasi zidnog namještaja stambenog dijela kompleksa nose oznake 16 . stoljeća.

Sjeverna gospodarska prizemnica, danas pretvorena u vrt, građena je grubo klesanim kamenim blokovima. Veća južna gospodarska zgrada građena je kamenom nešto finije obrade. Pročelje je otvoreno vratima i trima prozorima jednostavnih okvira. Na začelnom zidu su četiri puškarnice, jednake onima na manjoj gospodarskoj zgradi, od kojih su dvije zapunjene, a dvije zaklonjene bočnim zidom kapelice. $\mathrm{Na}$ istom zidu vidljivi su tragovi svodova koji nam govore da je ova zgrada nekad bila presvođena i nešto niža. U kasnijoj pregradnji dobila je otvoreno krovište.

Ispred ovog niza, sudeći po rupama na zidu, pružala se pergola.

U stražnjem dijelu kompleksa smješteni su kapelica, šetnica i vrtovi. Šetnica je u obliku slova »L«i popločana kamenom. Sa strana su podzidani dolci. Stupovi pergole su masivni i četvrtasti. Na jednom kraju šetnice je kapelica, a na drugom posebnost ovog ljetnikovca - vidikovac, odnosno terasa na vrhu cisterne. ${ }^{20} \mathrm{Na}$ vidikovac se moglo popeti kamenim stubama, a terasa je ograđena niskim zidićem.

Kapelica Gospe od Milosrđa, kao i većina crkvica koje su se nalazile u sklopu ladanjskih kompleksa, pravokutnog je tlocrta i presvođena bačvastim svodom. Dodana je kompleksu nešto poslije, jer je njezin bočni zid zatvorio puškarnice koje su se nalazile u začelnom zidu gospodarske zgrade. Kao i kuća, bila je porušena u prodoru Crnogoraca nakon pada Dubrovačke Republike. Obnovljena je tek 1919. godine o čemu svjedoči natpis nad portalom.

\section{Ladanjsko-gospodarski kompleks Ranjina-Capor u Komajima-Vignjima}

Kompleks koji je danas u vlasništvu obitelji Capor, za vrijeme Dubrovačke Republike pripadao je vlastelinima Ranjinama. ${ }^{21}$ Sklop se sastoji od kuće za stanovanje, gospodarskih zgrada, kapelice i vrtova. Sačuvan je dio ogradnog zida sa širokim ulazom. Cjelina se može podijeliti na istočno i zapadno krilo, a nastajala je u nekoliko faza kroz 16. i 17. stoljeće. Jedna od faza datirana je 1606. godinom koja je uklesana na portalu podruma zapadnog krila, a sudeći po nepravilnijem načinu gradnje i klesanja kamene građe te zatvorenosti zidnog plašta, istočno krilo nastalo je nešto prije.

Prostorije za stanovanje bile su smještene na katu zapadnog krila. U podrumu su prostori gospodarske namjene, kao i u cijelom istočnom krilu.

Ispred istočnog krila kojim dominira središnji dvoetažni dio, pružala se odrina o čemu svjedoče rupe u pročelnom zidu. Na zidnom plaštu vidljivo je nekoliko različitih obrada

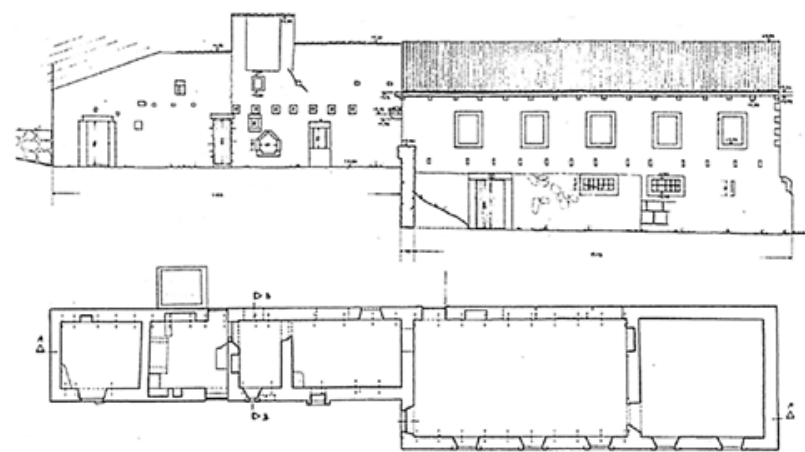

3. Ladanjsko-gospodarski kompleks Ranjina-Capor, KomajiVignji, tlocrt i pogled na pročelje / The residential-farming complex Ranjina-Capor, Komaji-Vignji, ground plan and view of the house front

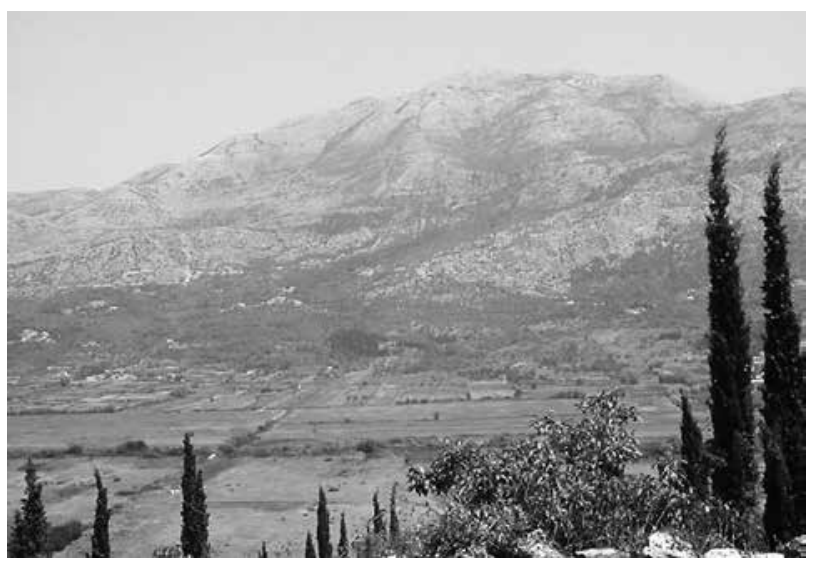

4. Ladanjsko-gospodarski kompleks Ranjina-Capor, KomajiVignji, pogled na Konavosko polje i Sniježnicu / The residentialfarming complex Ranjina-Capor, Komaji-Vignji, view of the Konavle Plain and Sniježnica hill

kamena i načina gradnje. U jednoj od prostorija u unutrašnjosti smještena je kuhinja s ostacima dviju peći.

Zapadno krilo je također nastajalo u nekoliko faza. $\mathrm{Na}$ nadvratniku portala u prizemlju nalazi se medaljon s natpisom »IHS«i uklesanom godinom 1606., no finija obrada kamenih blokova slaganih u pravilne redove upućuje na to da su naknadno dodani još jedna prostorija u podrumu i cijeli kat. $\mathrm{Na}$ zapadnoj fasadi nalaze se zazidani široki lučni otvor i tragovi dvoslivnog krova, a sjeverna fasada završena je slobodnim kamenim blokovima. $\mathrm{U}$ unutrašnjosti podruma nasuprot ulazu ostaci su krušne peći, a uz nju je smješteno jednostavno pilo.

Pročelje kata na kojem se stanovalo otvoreno je s pet prozora jednostavnih okvira i završava nizom konzola koje nose kameni žlijeb za odvod vode. Ovaj dio građevine ima komunikaciju s terasom pred kompleksom, kao i sa stražnjim vrtom. U južnom vrtu nalazimo tragove još jednog dijela kuće, vidljivog i na katastarskom planu iz 1837. godine. Sačuvani su dijelovi zida, južna fasada ovog dijela kuće je još uvijek ožbukana, a na zubove koji su nekad nosili stropne grede 
naslonjen je još jedan red konzola koje sada nose kameni žlijeb za odvod vode. Ovaj dio je mogao sadržavati dvije sobe koje su imale danas zazidane ulaze iz središnje dvorane.

U unutrašnjosti zapadnog krila sačuvan je niz kamenih konzola plitko profiliranih rubova koje su nosile stropne grede. Velika središnja dvorana je ujedno i središte komunikacije. U pregradnom zidu je jednostavno oblikovan zidni ormar. Kameni zidni umivaonik se nalazi uz vrata prema južnom vrtu, a jedini su mu ukras profilirane baze i vijenac nad poprečnom gredom. Iz obje prostorije stambenog krila moglo se uživati u pogledu na Konavosko polje i Sniježnicu.

Kapelica sv. Ivana smještena je istočno od objekta. ${ }^{22}$ Pravokutnog je tlocrta i otvorenog krovišta. Zapadno pročelje sadrži jednostavan portal s profiliranim vijencem iznad nadvratnika, malu rozetu i preslicu na jedno zvono ukrašenu plitkim volutama. Dok je južni zid otvoren jednostavnim četvrtastim prozorom, na sjevernom je zidu uski prozor lučno zaključen istaknutim zaglavnim kamenom.

Zapadno od kompleksa nalazila se još jedna gospodarska zgrada od koje su danas sačuvani ostaci zidova i mlina za masline. ${ }^{23}$

\section{»Diklićeva taraca« u Čilipima- Masješama}

Ladanjsko-gospodarski kompleks u Masješama, zaselku Čilipa, naziva se Diklićeva taraca po obitelji u čijem je vlasništvu od kraja 19. stoljeća. Smješten je na povišenoj glavici, na osami, uz nekadašnju seosku komunikaciju koja danas više nije u funkciji. Unutar ogradnog zida nalaze se dvije stambene jedinice, gospodarski prostori, kapelica i vrt s vidikovcem na prostranoj ograđenoj terasi. Veličina, razvijena tlocrtna organizacija i obrada kamenih dijelova izdvajaju ga od ostalih objekata sličnog karaktera.

Sjeverna stambena kuća je jednokatnica sačuvana do visine krova. $U$ unutrašnjosti se duž zidova nalaze nizovi kamenih konzola koje su nosile stropne grede prizemlja i kata. Kat je opremljen kamenim namještajem. Jednostavni zidni ormar profiliranoga unutrašnjeg ruba okvira smješten je u pročelnom zidu između dva prozora, a zidni umivaonik nalazi se na susjednom južnom zidu. Istaknuti poligonalni rub bazena pila ukrašen je gotičkim motivom izmjeničnih zubaca i flankiran motivom plitkih reljefnih konzolica. Poviše poprečne grede je profilirani vijenac. Ovakav spoj gotičkog ukrasa i renesansnih oblika nalazimo u kamenom namještaju s početka 16 . stoljeća. ${ }^{24}$

Povezan s obje kuće je ruševan prostor kuhinje s ostacima peći i zidnim ormarom jednako oblikovanim kao što je onaj na katu kuće.

Južna zgrada dominira kompleksom zbog svoje veličine, obrade zidova i okvira otvora, te pravilne tlocrtne organizacije.

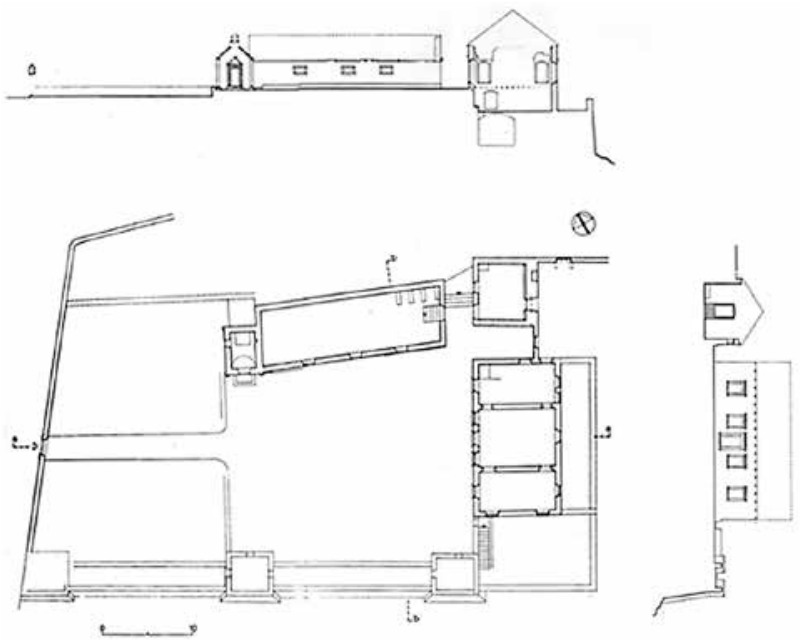

5. »Diklićeva taraca«, Čilipi-Masješe, tlocrt i presjeci / The Diklić Terrace, Čilipi-Masješe, ground plan and sections

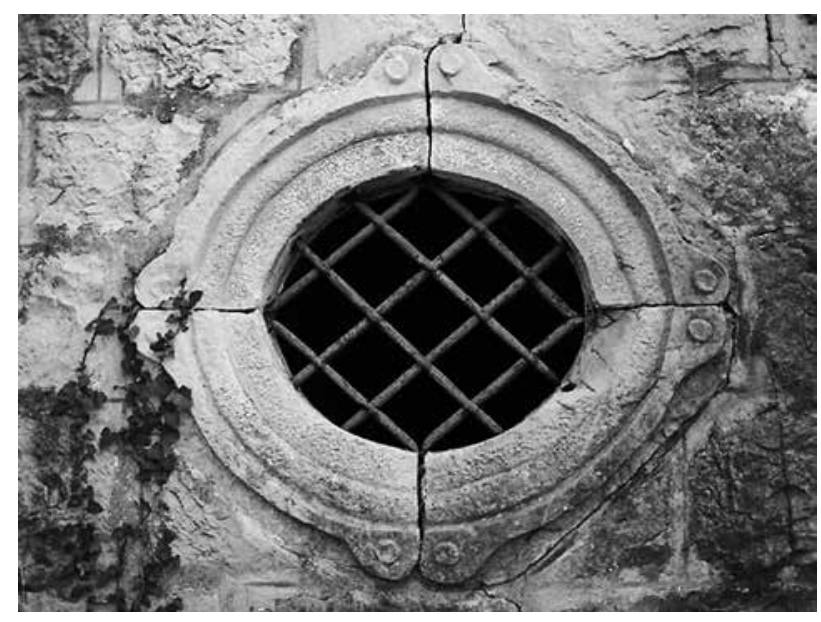

6. »Diklićeva taraca«, Čilipi-Masješe, bočni prozor kapelice / The Diklić Terrace, Čilipi-Masješe, side window of the chapel

Danas jebezkrova, a prema lokalnoj predaji zbog obiteljske svađe nikad nije bila ni dovršena ni nastanjena. Zidovi su građeni fino klesanim kamenim blokovima slaganim u pravilne redove, a zaključeni su nizom konzola. Prostorije za stanovanje nalazile su se na katu dok je podrum imao gospodarsku namjenu. U slučaju kata možemo reći da je planirana uobičajena tlocrtna shema dubrovačkih ljetnikovaca, s velikom središnjom dvoranom i manjim bočnim prostorijama. Unutrašnji raspored se ogleda i na fasadi pa središnja dvorana ima otvore većih dimenzija. Svi su okviri fino klesani, prozorske klupice su profilirane, a poviše natprozornika su profilirani vijenci.

U unutrašnjosti kata sačuvana su dva okvira vrata. Ravnom okviru ulaznih vrata u sjevernoj bočnoj prostoriji dodan je profilirani vijenac nad nadvratnikom, dok su vrata između središnje i južne bočne sobe ukrašena kontinuiranom dubokom profilacijom s oblim štapom u sredini. Iznad 
okvira je profilirani kameni vijenac, a na dnu svakog nadvratnika je uklesan motiv romba. ${ }^{25}$ Svi elementi dekoracije klesanih dijelova javljaju se kroz 16 . stoljeće.

U podrum se silazi vanjskim kamenim stubištem. Nosivi lukovi dijele ovaj prostor na tri dijela, a u središnjem se nalazi otvor cisterne.

Prizemna gospodarska zgrada, smještena okomito na stambeni niz, danas je sačuvana do visine krova. Vrtna fasada je rastvorena trima malim prozorima u obliku položenog pravokutnika. U unutrašnjosti su četiri monolitna kamena bloka na koja su mogle biti naslonjene bačve, pa je ovdje vjerojatno bio smješten vinski podrum.

Na gospodarsku je zgradu naslonjena kapelica baroknih obilježja posvećena Gospi od Rozarija. Pravokutnog je tlocrta i presvođena bačvastim svodom. Na vanjskim uglovima se nalaze pilastri na bazama is fragmentima gređa umjesto kapitela. Pročelje sadrži ukrašeni portal i rozetu u obliku križa te preslicu na jedno zvono. Zidovi su zaključeni vijencem. Slobodni bočni zid otvoren je malim ovalnim prozorom čiji je okvir ukrašen plitkom profilacijom sa stiliziranim motivom voluta. Iznad profiliranoga kamenog portala kapelice je glatki friz te prekinuti zabat. Unutrašnjost kapele je popločana. Duž bočnih zidova na mjestu spajanja zida i svoda teče razdjelni vijenac. U bočnom zidu nasuprot prozora nalazi se mala polukružna zidna niša, smještena unutar okvira iznad kojeg je istaknuti vijenac s volutama na vrhu. Barokna dekoracija upućuje nas na to da je kapelica dodana sklopu u 17. stoljeću.

Prostrani vrt smješten je na ograđenoj terasi. Od ulaznoga kamenog portala, koji je djelomično sačuvan u ogradnom zidu, vodi šetnica između podzidanih dolaca. Može se naći i poneki kameni stup, ostatak nekadašnje pergole. Najznačajniji dio je dugačka šetnica-vidikovac koja se pružala duž južne strane vrta. Izvana je ljetnikovac izgledao poput utvrde zbog visokog zida terase pojačanog trima istaknutim volumenima raspoređenim u pravilnim razmacima. $\mathrm{Na}$ vrhu toga zida nalazila se zapravo šetnica koja je povezivala tri vidikovca. Sve je bilo ograđeno niskim zidićima koji su završavali kamenim pločama profiliranih rubova. Na vidikovce se moglo ulaziti i iz vrta. S ovog mjesta pružao se pogled na okolicu i more. Danas je jedan vidikovac srušen, a šetnica je gotovo neprohodna. Velik dio vrta je zarastao. Cijeli je kompleks zapušten i u ruševnom stanju. Redovito godišnje održavanje crkvenih obreda u kapelici je napušteno.

\section{Ladanjsko-gospodarski kompleks Pucić-Rešetar u Čilipima}

Nekadašnji ladanjsko-gospodarski kompleks dubrovačke vlasteoske obitelji Pucić nalazi se u polju jugozapadno od središnjega čilipskog trga i župne crkve. U prvoj polovini 19. stoljeća dolazi u vlasništvo Marka Klaića, a od 1848. godine u
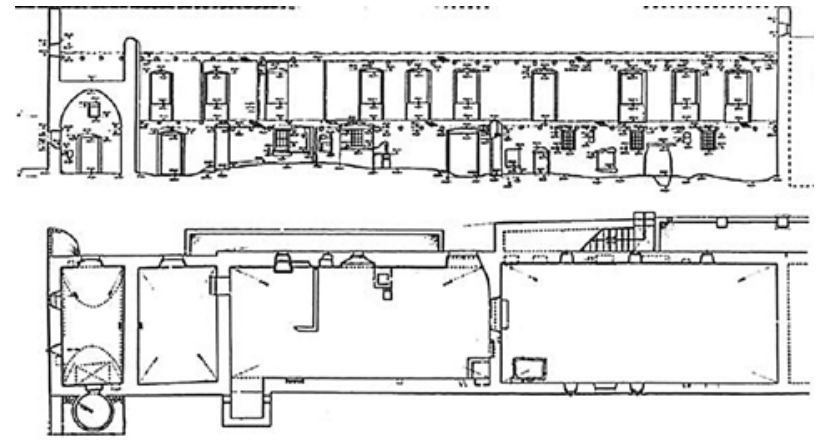

7. Ladanjsko-gospodarski kompleks Pucić-Rešetar, Čilipi, tlocrt i presjek / The residential-farming complex Pucić-Rešetar, Cilipi, ground plan and section

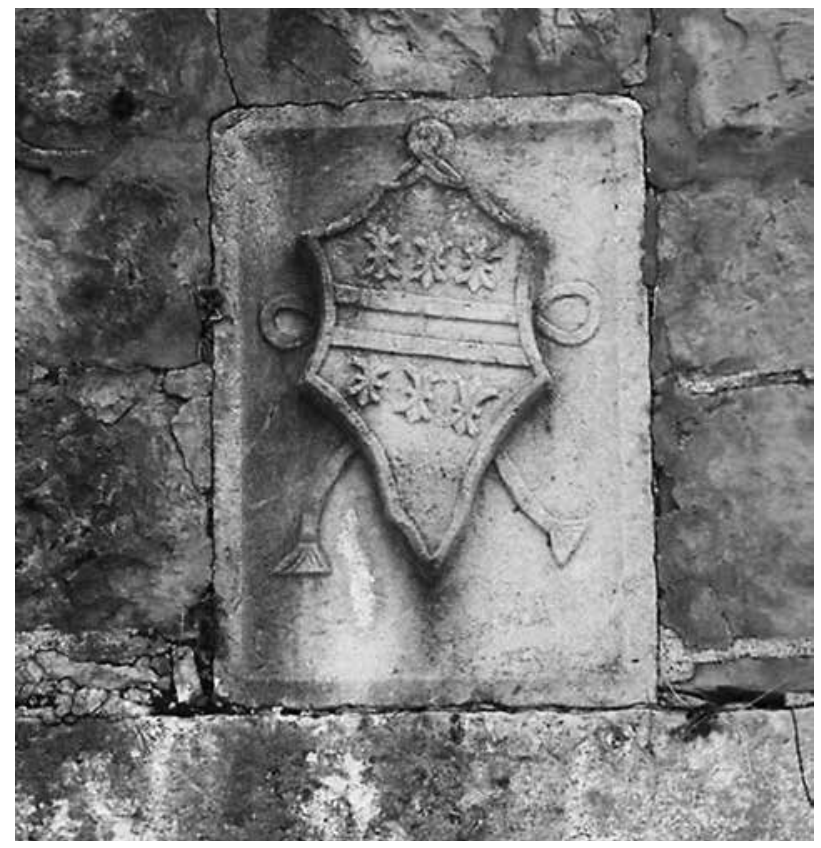

8. Ladanjsko-gospodarski kompleks Pucić-Rešetar, Čilipi, grb obitelji Pucić / The residential-farming complex Pucić-Rešetar, Čilipi, Pucić family coat of arms

vlasništvu je obitelji Rešetar. Godine 1857. u zgradu je smještena pučka škola za šire područje Konavala otkuda dolazi i jedan od naziva lokaliteta (»Stara škola»). Tijekom rata 1991. godine zgrada je izgorjela i danas je u ruševnom stanju. ${ }^{26}$

Ovaj kompleks čine izdužena jednokatnica, kapela i vrt sa šetnicom. Jednokatnica je naknadno bila spojena s prvobitnom kapelicom koja je prenamijenjena u peć s dimnjakom. ${ }^{27}$ Današnja kapela smještena je $u$ vrtu. Stambeno-gospodarski sadržaji su građeni u nizu.

Glavna zgrada ima dvojnu funkciju. Prizemlje je gospodarsko, dok su na katu bile stambene prostorije. Na vanjskim zidovima primjetna je fina obrada kamenih blokova malih dimenzija slaganih u pravilne redove. Na glavnom južnom pročelju su u prizemlju široka vrata. Kameni okvir vrata 
ukrašen je oblim rubnim štapom, a poviše nadvratnika je ploča na kojoj je isklesan grb obitelji Pucić, s dvije kose pruge i po tri ljiljana u svakom polju. ${ }^{28} \mathrm{Na}$ kat vodi vanjsko kameno stubište sa zidanom ogradom. Pročelni prozorski okviri kata ukrašeni su rubnim štapom. Zidovi su izvana završeni nizom konzola s kamenim žlijebom za odvod vode.

Budući da su podna konstrukcija i pregradni zidovi uništeni, možemo samo pretpostavljati kakav je, prije prenamjena i spaljivanja, mogao biti izvorni tlocrtni raspored.

U gospodarskom prizemlju se nalaze cisterna i velika peć, a jedan od malih prozora umjesto prozorske klupice ima jednostavno kameno pilo.

Glavni korpus zgrade naknadno je lošije izvedenom nadogradnjom bio spojen s prvobitnom kapelicom. Nekadašnja kapelica je pravokutnog tlocrta, presvođena gotovo šiljastim svodom. Jedina dekoracija sačuvana do danas je profilirani kameni vijenac duž unutrašnjih bočnih zidova. $\mathrm{Na}$ mjestu oltara nalazi se krušna peć, a »kominata« je smještena uz vanjski zid.

Nije poznato zašto je ova kapela napuštena i sagrađena nova, u vrtu istočno od glavne zgrade. Posvećena je Navještenju (lokalno "Nuncijata« po čemu lokalitet nosi ime). Smještena uz vrata u ogradnom zidu sklopa, osim vlasnicima, bila je dostupna i okolnom stanovništvu. Pročeljem je okrenuta prema šetnici. Tlocrt je u obliku nepravilnog pravokutnika jer oltarni zid kapele prati liniju ogradnog zida, a presvođena je bačvastim svodom. Okvir portala ukrašen je rubnim štapom i profiliranim vijencem nad nadvratnikom. Na bočnim zidovima je po jedan uski prozor zaključen šiljastim lukom. Izvana se u ogradnom zidu nalazi još jedan mali prozor s uskim otvorom za milodare koji su se mogli sakupiti iza oltara. Unutrašnjost ima kameno popločenje, a duž bočnih zidova kontinuira kamena profilacija.

$\mathrm{Na}$ osnovi skromne arhitektonske plastike gdje su još uvijek prisutni gotički elementi poput šiljastog luka koji se miješaju s renesansnim ukrasima, možemo pretpostaviti da je sklop nastao u 16. stoljeću.

Ispred glavne zgrade nalazi se prostrani vrt sa šetnicom u obliku slova »T«. Djelomično su sačuvani kameni stupići kvadratičnog presjeka na koje su bile naslonjene poprečne grede odrine.

\section{Ladanjsko-gospodarski kompleks Vodopić-Car u Zastolju}

Kako bismo dotakli i »Gornju bandu« Konavala, dodat ću ovdje kratki osvrt na ladanjsko-gospodarski kompleks u Zastolju koji je 1837. godine pripadao Vodopićima, a sastojao se od kuće za stanovanje, ruševine i crkve. ${ }^{29} \mathrm{U}$ štetama francuske komisije iz 1806. godine spominje se izgorjela

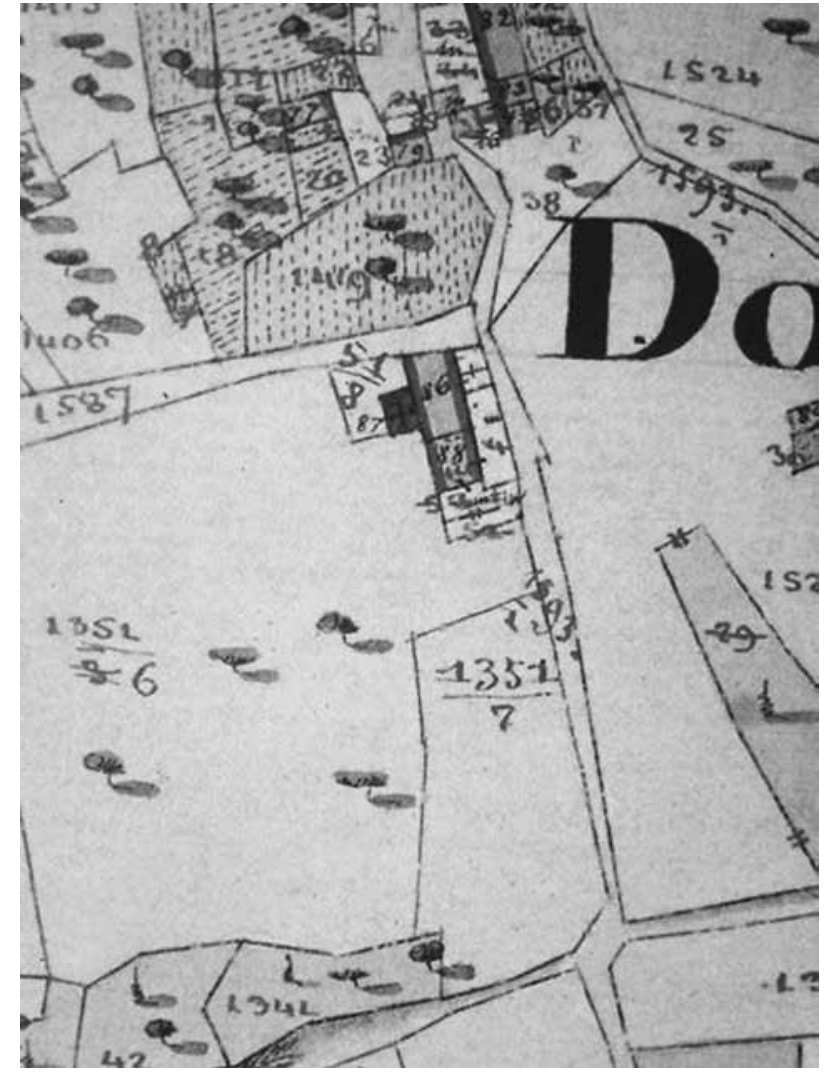

9. Ladanjsko-gospodarski kompleks Vodopić-Car, Zastolje, katastarska karta iz 1837. (Državni arhiv Split, Arhiv mapa za Istru i Dalmaciju) / The residential-farming complex Vodopić-Car, Zastolje, land registry survey map, 1837 (State Archives Split, Archive of the Maps of Istria and Dalmatia)

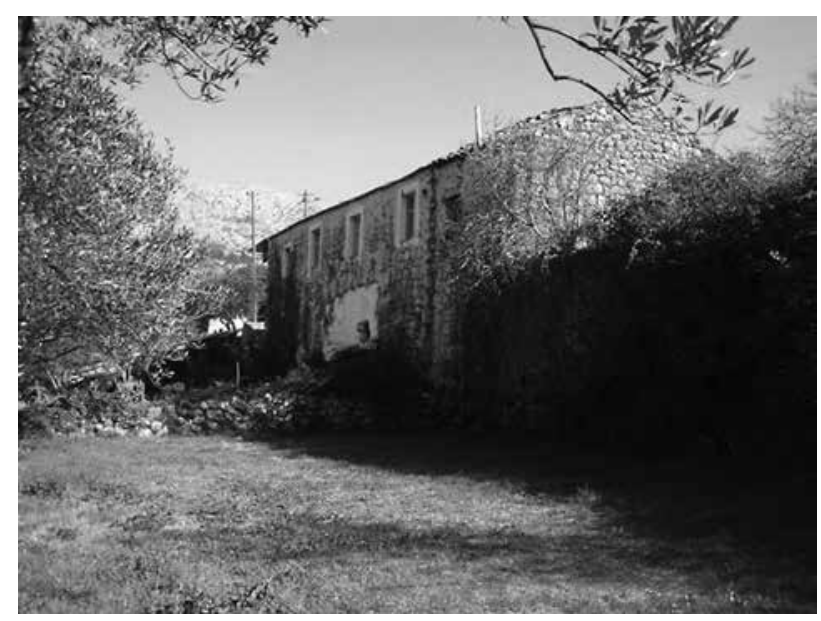

10. Ladanjsko-gospodarski kompleks Vodopić-Car, Zastolje, pogled na južnu fasadu / The residential-farming complex VodopićCar, Zastolje, view of the south front

kuća, stranj i kapela u vlasništvu obitelji Balettini. ${ }^{30}$ Današnji vlasnik je obitelji Car. Iako pregrađen, zadržao je izvorne gabarite i neke elemente prvobitnog izgleda. Sastoji se od glavne zgrade, donje gospodarske i gornje stambene etaže, 
na koju se prema istoku nastavlja prizemnica sačuvana do visine krova. Duž prizemne zone južnog pročelja tri su uske uspravne puškarnice pravokutnog oblika koje se ponavljaju i u zidu ruševine. ${ }^{31} \mathrm{U}$ istoj zoni sjevernog pročelja ugrađena su vrata plitko profiliranog okvira.

Uz južno pročelje bila je prislonjena kapela sv. Roka. Još uvijek su vidljivi tragovi žbuke na tom mjestu. Prema kazivanju vlasnika, kapela je u 20. stoljeću dislocirana zapadno od kuće i služi kao seoska kapela. Okvir ulaznih vrata plitko je profiliran, s Kristovim monogramom u središtu nadvratnika te vijencem nad njim. Ostaci profiliranih okvira nagovještavaju nam izgled i opremu nekadašnjeg zdanja i upućuju nas na 16. stoljeće kao vrijeme njihova nastanka.

\section{Zaključak}

Izgradnja ladanjsko-gospodarske arhitekture u Konavlima intenzivirala se u 16. i 17. stoljeću, nakon što su se smirile burne povijesne prilike tijekom i neposredno nakon priključenja Konavala prostoru Dubrovačke Republike. Kao i u ostalim dijelovima Republike usmjerenim na poljoprivredu, poput primjerice otoka Šipana, uobičajeno je da najveći dio objekta, pa čak i dijelove stambene kuće, zauzimaju gospodarski sadržaji. ${ }^{32}$ Prostorije za privremeni boravak na posjedu bile su opremljene kamenim namještajem jednostavnoga skulpturalnog ukrasa, a otvoreni prostori sa šetnicama, pergolama i vidikovcima činili su boravak na imanju ugodnim. Kompleksi su zatvoreni visokim ogradnim zidovima i gotovo u pravilu nailazimo na prisutnost obrambenih arhitektonskih elemenata poput puškarnica i vidikovaca nalik utvrdama.

Iz opisanih primjera razvidno je da su ladanjsko-gospodarski kompleksi u Konavlima, vrijedno arhitektonsko naslijeđe iz vremena Dubrovačke Republike, u zabrinjavajućem stanju. Nakon velikih oštećenja koje su pretrpjeli poslije pada Republike, rijetki su u potpunosti obnovljeni, barem ne u svom punom sjaju. Nisu bili pogodni za život zadružnih konavoskih obitelji pa su pretvoreni u štale, sjenike, mlinice. Ako su ostali nastanjeni, s vremenom su prilagođeni novim životnim potrebama. Na nekima su sagrađene kuće ili su jednostavno razgrađeni i nestali. Posljednja oštećenja su doživjeli u potresu 1979. godine i ratu 1991. godine i najvećim dijelom nisu obnovljeni. Ostaje nada da će biti osviještena njihova prisutnost u prostoru Konavala, makar to bilo samo putem pisane riječi.

\section{IZVORI SLIKOVNIH PRILOGA}

Nada Grujić, Ladanjska arhitektura dubrovačkog područja, Institut za povijest umjetnosti, Zagreb, 1991. (sl. 1, 7)

Međunarodna ljetna radionica Konavle 97, (ur.) Bruno Diklić, Ministarstvo kulture RH, Zagreb, 1998. (sl. 3, 5)

\section{BILJEŠKE}

1 NADA GRUJIĆ, Ladanjska arhitektura dubrovačkog područja, Institut za povijest umjetnosti, Zagreb, 1991., 157, 162-163.

2 Državni arhiv u Dubrovniku (dalje: DAD), Commission de liquidation Francaise, No. 11804. Canali, XII, 1806. (prema kopiji izvornog dokumenta).

3 JOSIP LUČIĆ, Kroz konavosku prošlost, Konavoski zbornik, I (1982.), $13-21$.

4 VINKO FORETIĆ, Povijest Dubrovnika do 1808., I., Nakladni zavod MH, Zagreb, 1980., 190; ZDENKA JANEKOVIĆ, Stjecanje Konavala: antička tradicija $i$ mit $u$ službi diplomacije, Konavle u prošlosti, sadašnjosti i budućnosti, I., (ur.) Vladimir Stipetić, Zavod za povijesne znanosti HAZU, Dubrovnik, 1998., 32-42; PAVO ŽIVKOVIĆ, Ustupanje Konavala Dubrovčanima, Konavle u prošlosti, sadašnjosti i budućnosti, I., (ur.) Vladimir Stipetić, Zavod za povijesne znanosti HAZU, Dubrovnik, 1998., 77-81.

5 Do sada uvriježenu podjelu na istočni dio Konavala kao Sandaljev i zapadni dio kao Pavlovićev korigira Niko Kapetanić analizom podjele zemlje nakon stjecanja Konavala iz koje proizlazi da Pavlović posjeduje zapadni dio Konavala, dok su u središnjem i istočnom dijelu Pavlovićevi i Sandaljevi posjedi bili izmiješani. Više u: NIKO KAPETANIĆ, Konavle u XV. stoljeću, Matica hrvatska Konavle, Gruda, 2011., 19.

6 VINKO FORETIĆ (bilj. 4), 191.

7 Sandaljeva palača u Dubrovniku srušena je u potresu 1667. godine, ali iz niza sačuvanih arhivskih dokumenata saznajemo da je javnim novcem trebala biti sagrađena na reprezentativnom mjestu uz Knežev dvor. Riječ je o trokatnici pročelja rastvorenog prozorima šiljastog luka i balkonom te zaključenoj balatorijem. Skulpturalne ukrase imali su izraditi najbolji majstori toga vremena poput Bonina iz Milana, a dvoranu i jednu sobu imao je oslikati Đivan Ugrinović; NADA GRUJIĆ, Reprezentativna stambena arhitektura, Zlatno doba Dubrovnika, XV. i XVI. stoljeće, katalog izložbe, Muzejski prostor, Zagreb, 1987., 69; NADA GRUJIĆ, DANKO ZELIĆ, Palača vojvode Sandalja Hranića u Dubrovniku, Anali Zavoda za povijesne znanosti HAZU u Dubrovniku, 48 (2010.), 47-132.

8 VINKO FORETIĆ (bilj. 4), 192; NIKO KAPETANIĆ (bilj. 5), 13. Nakon prodaje svoga dijela Konavala Dubrovčanima, Radoslav Pavlović od njih je zahtijevao nagradu jednaku Sandaljevoj i veću svotu novca za uređenje poklonjene mu kuće, a majstori koji sudjeluju u gradnji Sandaljeve palače imali su izraditi klesane dijelove i za Pavlovićevu kuću; NADA GRUJIĆ, DANKO ZELIĆ (bilj. 7), 92-94.

9 Zemlja se u Konavlima, jednako kao u Primorju i na Pelješcu, dijeli na desetine koje se sastoje od deset dijelova. Dio se dijeli na dvije polovice, a svaka polovica na dvije četvrtine. Pritom je četvrtina najmanji dio koji se pri diobi može dobiti; NIKO KAPETANIĆ (bilj. 5), 20-21. Godine 1423. na teren je izašla komisija za podjelu zemlje otkupljene od Sandalja. Zemlja je nakon ugušene pobune vlasteličića podijeljena na 36 desetina. Godine 1427. provedena je druga podjela zemlje na 38 desetina. Područje Oboda, Cavtata, Uskoplja, Luga u Konavoskom polju i Površi podijeljeno je u dodatke (đonte) koje su dodane svakoj desetini. Zbog ponovnih nemira, podjela konavoskih Planina mogla je biti izvršena tek 1442. godine. Zemlja je podijeljena u 45 desetina. NIKO KAPETANIĆ (bilj. 5), 20-24, 36.

10 NIKO KAPETANIĆ (bilj. 5), 20-24.

11 DRAGAN ROLLER, Agrarno-proizvodni odnosi na području Dubrovačke Republike od XIII. do XV. stoljeća, JAZU, Zagreb, 1955., 242-244.

12 MARIJA PLANIĆ LONČARIĆ, Planirana izgradnja na području Dubrovačke Republike, Institut za povijest umjetnosti, Zagreb, 1980., 108.

13 Mihoč Radišić 1421. godine zida crkvu bosanskom vojvodi Sandalju Hraniću; CVITO FISKOVIĆ, Naši graditelji i kipari 15. i 16. stoljeća u Dubrovniku, Matica hrvatska, Zagreb, 1947., 93.

14 MARIJA PLANIĆ LONČARIĆ (bilj. 12), 105-115; ANĐELKO BADURINA, Uloga franjevačkih samostana u urbanizaciji dubrovačkog područja, Institut za povijest umjetnosti, Zagreb, 1990., 56, 95-96, 115-118. 15 "Stranjem« se nazivaju gospodarske zgrade u kojima se skupljaju, skladište, prerađuju i dalje distribuiraju prinosi i proizvodi s posjeda; 
Vid Vuletić Vukasović u jednoj zabilješci navodi: „Stranj bijaše vrst konobe u kojoj gospar točiše vino iz svog vlastitog vinograda (a dolazi od lat. subterraneum)«, Arhiv dominikanskog samostana u Dubrovniku, Arhiv Nika Nardellija, 37-IV-8; Naziv »stranj« zadržao se do danas, često označava nekadašnji ladanjsko-gospodarski kompleks, kao i gospodarske zgrade i prostorije.

16 DAD, Commission de liquidation Francaise, No. 11804. Canali, XII, 1806. (prema kopiji izvornog dokumenta).

17 Državni arhiv u Splitu (dalje: DAS), Arhiv mapa za Istru i Dalmaciju, Katastarske mape i katastarske knjige Radovčića, 1837.

18 RAFO BOGIŠIĆ, Pjesnici starog Dubrovnika na ladanju u Konavlima, Konavle u prošlosti, sadašnjosti i budućnosti, II., (ur.) Vladimir Stipetić, Zavod za povijesne znanosti HAZU, Dubrovnik, 1999., 19-23.

19 Ovako klesano pilo, izrazitih stilskih obilježja, nalazimo u nekadašnjem kompleksu Natalić-Kocelj-Montgomery u Močićima, odnosno u današnjoj kući Kocelj. Njega krase dublja profilacija okvira i motiv školjke flankiran volutama na bazi. Ovaj tip zidnog umivaonika javlja se već krajem 15. stoljeća, i možemo ga usporediti s pilom u trijemu Restićeva ljetnikovca u Rijeci dubrovačkoj iz sredine 16. stoljeća; NADA GRUJIĆ, Zidni umivaonici XV. i XVI. stoljeća u stambenoj arhitekturi dubrovačkog područja, Radovi Instituta za povijest umjetnosti, 23 (1999.), 70-74.

20 NADA GRUJIĆ (bilj. 1), 162.

21 Pri podjeli Sandaljeva dijela Konavala 1423. godine, Ranjine nisu dobili zemlju u Vignjima. Oko 1750. godine u Vignjima posjede ima Savin Franov de Ragnina. Iz popisa šteta 1806. godine vidljivo je da je vlasnik tada spaljene kuće bio Orsat, sin Luja Savinova de Ragnina; NIKO KAPETANIĆ, Konavoski epigrafički spomenici iz vremena Dubrovačke Republike, Zavod za povijesne znanosti HAZU, Zagreb-Dubrovnik, 2000., 118-119.

22 Nakon što je izgrađena ova kapela, prijašnja seoska crkva sv. Ivana, smještena južno od sela, napuštena je; NIKO KAPETANIĆ (bilj. 5), 241-242. Također, u Knjigama vjenčanih župe Čilipi zabilježeno je vjenčanje Jelene, kćeri Orsata de Ragnina, i Nika Lucijanova de Pozza koje se dogodilo 11. srpnja 1813. godine u kapeli sv. Ivana u Vignjima; NIKO KAPETANIĆ (bilj. 21), 118-119.

23 Posljednjih godina izrađen je projekt obnove ovog objekta u turističke svrhe. Tom prilikom izvedena su i arheološka istraživanja. Projekt i rezultati istraživanja nisu mi u potpunosti poznati.
24 NADA GRUJIĆ (bilj. 19), 69.

25 Jednak okvir vrata ugrađen je u ogradnom zidu kuće Diklić u Močićima. Skulpturalni ukras ovog okvira vrata možemo usporediti s okvirima vrata dvorane prvog kata Restićeva ljetnikovca u Rijeci dubrovačkoj iz 16. stoljeća (NADA GRUJIĆ, Vrijeme ladanja, Matica hrvatska, Dubrovnik, 2003., 48-49), s tom razlikom što kod konavoskog primjera profilacija okvira dobiva na plasticitetu.

26 Državna uprava za zaštitu kulturne i prirodne baštine, Čilipi, konzervatorska studija, Zagreb, 1996., 35.

27 Državna uprava za zaštitu kulturne i prirodne baštine, Podaci o ratnoj šteti, Dubrovnik, 1994.

28 Grbovi dubrovačkih obitelji, osim na Pucićevoj kući u Čilipima, javljaju se još na nekoliko mjesta: u Čilipima na kruni bunara obližnjeg objekta Getaldić-Vezilić, u Močićima u kompleksu Natalić-KoceljMontgomery dva su grba na oltaru kapele, na pročelju kuće Bona-Radulović u Grudi ugrađen je Bonin grb. Također, u obližnjoj kući Vidak u Grudi, koja je nekada pripadala dubrovačkom pjesniku Bernardu Zamanji (1735.-1820.), nalazio se natpis na kamenoj ploči, epigram koji je sastavljen nakon spaljivanja njegove konavoske ville 1806. godine. Cijeli natpis koji je ponovo stradao u posljednjem ratu trenutačno je na restauraciji, donosi Kapetanić u: NIKO KAPETANIĆ (bilj. 21), 106-108.

29 DAS, Arhiv mapa za Istru i Dalmaciju, katastarske knjige za Zastolje, 1837.

30 DAD, Commission de liquidation Francaise, No. 11804. Canali, XII, 1806. (prema kopiji izvornog dokumenta).

31 Puškarnice nisu rijetkost u ovako udaljenim krajevima Republike, naročito ne u nemirnim Konavlima. Na Kneževu dvoru u Pridvorju u obliku su ključanice (KATARINA HORVAT LEVAJ, Knežev dvor u Pridvorju - građevni razvoj i problem obnove, Radovi Instituta za povijest umjetnosti, 20 (1996.), 109), kao i na utvrđenom kompleksu Saraka-Pulić u Dubravci-Pičetama. Na kompleksu Božidarević-Bačan u Komajima-Grušićima kružne puškarnice kontinuiraju duž sjevernog pročelja. U Radovčićima, na gospodarskoj zgradi Crijević-Lobro, javljaju se visoko postavljene u obliku položenog pravokutnika.

32 NADA GRUJIĆ (bilj.1), 156-164; NADA GRUJIĆ, Ladanjsko-gospodarska arhitektura 15. i 16. stoljeća na otoku Šipanu, Zbornik Dubrovačkog primorja i otoka, II (1988.), 223-274. 
Summary

\section{Lucija Vuković}

\section{The Architecture of the Mansions in the Konavle Region}

In the 15th and 16th century the Dubrovnik Republic expanded its territory and secured its borders. Being the last territory to join the Republic during the 15th century, the situation in Konavle was rather unstable, owing to uprisings of the local population, clashes with neighbouring nobles, and Ottoman inroads. Building on country estates and farms came to life only when the political situation became more peaceful and secure. The residential-farming complexes of Konavle cannot be reduced to one architectural model. What they had in common were the walls encircling the estates, protecting the rather modest $d$ wellings and more dominant farming structures, arranged in a row or grouped around the central building.

The central building was the largest in size, with carefully finished outside walls and well carved stone frames of doors and windows. One floor was residential, and the other was used for household and farming activities. The arrangement and function of the rooms follows no rules, but it was customary to have one large central hall which is the hub of the complex. These halls were provided with usually sparely decorated stone furnishings.

The small chapels were the most representative parts of such complexes. They bear the characteristics of their period, have been refurbished through the centuries and survived to the present day.

The gardens, situated at the front or back of the main building, were criss-crossed by walking paths covered by awnings. They have been neglected through the years or turned into vegetable plots, which makes it almost impossible to reconstruct their original state.

Today the residential-farming complexes of Konavle are mostly neglected. After the fall of the Dubrovnik Republic they were subjected to various kinds of devastation shared by the entire region. Most of them have not been fully operative for many years, and some have been reduced to some kind of farm work. 